\title{
Respon Eksplan Vanili (Vanilla planifolia) dengan Stimulasi BAP dan NAA Melalui Teknik Mikropropagasi
}

\author{
The response of Vanilla Explant (Vanilla planifolia) to BAP and NAA Stimulation \\ through Micropropagation Technique
}

\author{
Author(s): Dyah Nuning Erawati ${ }^{(1) *}$; Usken Fisdiana ${ }^{(1)}$ Muhammad Kadafi $^{(1)}$ \\ (1) Politeknik Negeri Jember \\ * Corresponding author: dyah_nuning_e@polije.ac.id
}

\author{
Submitted: 16 Jul $2020 \quad$ Accepted: 31 Aug $2020 \quad$ Published: 30 Sep 2020
}

\begin{abstract}
ABSTRAK
Pengembangan tanaman vanili dengan perbanyakan vegetatif secara konvensional memiliki keterbatasan tanaman induk sebagai bahan setek sehingga vanili berpotensi dikembangkan melalui teknik mikropropagasi. Kemampuan eksplan vanili dalam beregenerasi dan berdiferensiasi untuk membentuk tunas dan akar secara in vitro perlu dikontrol melalui pengaturan auksin dan sitokinin. Tujuan dalam penelitian adalah: 1) menganalisis respon eksplan vanili dengan stimulasi BAP; 2) menganalisis respon eksplan vanili dengan stimulasi NAA dan 3) menganalisis interaksi stimulasi BAP dan NAA terhadap respon eksplan vanili melalui teknik mikropropagasi. Penelitian dilaksanakan di laboratorium Kultur Jaringan Politeknik Negeri Jember menggunakan Rancangan Acak Lengkap (RAL) faktorial. Faktor 1 adalah stimulasi BAP pada level konsentrasi $0.0,1.0,3.0 \mathrm{mg} / \mathrm{L}$ dan faktor 2 adalah stimulasi NAA pada level konsentrasi $0.0,0.5 \mathrm{mg} / \mathrm{L}$. Hasil penelitian memperlihatkan bahwa stimulasi BAP secara tunggal mempengaruhi multiplikasi tunas vanili dengan rerata jumlah tunas terbanyak 6.8 tunas/ eksplan pada stimulasi BAP $1 \mathrm{mg} / \mathrm{L}$ dan stimulasi NAA secara tunggal menginduksi pembentukan akar dengan rerata jumlah akar terbanyak 3.0 akar/eksplan pada stimulasi NAA $0.5 \mathrm{mg} / \mathrm{L}$.
\end{abstract}

Kata Kunci:

BAP;

Eksplan;

NAA;

Mikropropagasi;

Vanili.

\section{Keywords:}

$B A P$;

Explant;

$N A A$;

Micropropagation;

Vanilla.

\section{ABSTRACT}

The development of vanilla plants with conventional vegetative propagation has limitations as a parent plant cuttings. Vanilla is potentially developed by micropropagation. The ability of vanilla explants to regenerate and differentiate to form shoots and roots in vitro needs to be controlled by regulation auxins and cytokines. Interest in the study was: 1) study the response of vanilla explants with BAP stimulation; 2) study the response of vanilla explants with NAA stimulation and 3) the interaction stimulation of BAP and NAA to the response of vanilla explants by micropropagation. The experiment was conducted in Laboratory Tissue Culture Politeknik Negeri Jember using a Completely Randomized Design (CRD) factorial. Factor 1 is the stimulation of BAP at concentration levels of 0.0, 1.0, 3.0 mg/L, and the second factor is the stimulation of NAA in the concentration level of $0.0,0.5 \mathrm{mg} / \mathrm{L}$. The results showed that $B A P$ stimulation of $1 \mathrm{mg} / L$ resulted in the highest average number of shoots of 6.8 shoots/ explant and NAA stimulation of $0.5 \mathrm{mg} / \mathrm{L}$ had the highest average number of roots 3.0 roots / explant. 


\section{PENDAHULUAN}

Tanaman vanili (Vanilla planifolia Andrews) merupakan salah satu komoditi pertanian yang menghasilkan devisa negara bagi Indonesia. Posisi Indonesia menempati peringkat kedua setelah Madagaskar dengan produksi vanili sebesar 2.304 ton pada tahun 2016. Nilai ekspor vanili mencapai 72,511 ribu US dolar pada tahun 2017 tetapi menurun pada tahun 2018 dengan nilai ekspor 63,062 ribu US dolar (Loedji, 2019).

Perbanyakan vanili secara vegetatif konvensional dengan menggunakan setek batang (Palama et al., 2010). Namun pengembangan vanili dihadapkan pada kendala serangan penyakit layu Fusarium (Fusarium oxysporum) dan keterbatasan bahan tanam karena harus diambil dari sulur tanaman induk yang belum pernah berbuah Pinaria et al. (2010). Teknik mikropropagasi untuk perbanyakan vegetatif vanili telah banyak dikembangkan untuk mengatasi kendala tersebut.

Keberhasilan teknik mikropropagasi pada vanili sudah banyak dilaporkan. Penggunaan 9,5 $\mu \mathrm{M}$ BA pada media dasar MS menghasilkan rerata 18.5 tunas/eksplan setelah 5 minggu. Planlet setinggi 2-3 cm mampu membentuk sistem perakaran pada media $1 / 2$ MS dengan penambahan $4.45 \mu \mathrm{M}$ NAA (Lee-Espinosa et al., 2008). Lebih lanjut Ayele et al (2017) mengemukakan bahwa penambahan BAP $2 \mathrm{mg} / \mathrm{L}$ dan NAA 0.5 $\mathrm{mg} / \mathrm{L}$ menghasilkan tunas terbanyak dengan rerata 5.33 serta tinggi tunas 4.9 $\mathrm{cm}$. Hasil yang berbeda dilaporkan oleh Tan, et al. (2011) yang mengungkapkan bahwa hanya formasi kalus yang terbentuk pada eksplan vanili yang diinokulasikan pada media MS dengan penambahan 2 $\mathrm{mg} / \mathrm{L}$ NAA dan $1 \mathrm{mg} / \mathrm{L}$ BAP. Erawati, et al. (2020) juga melaporkan bahwa multiplikasi tunas vanili hanya dipengaruhi oleh BAP dengan hasil rerata tunas terbanyak 3 tunas/eksplan pada 28 hari setelah inokulasi.

Kemampuan eksplan vanili dalam beregenerasi dan berdiferensiasi untuk membentuk tunas dan akar secara in vitro perlu dikontrol melalui pengaturan auksin dan sitokinin. Oleh karena itu penelitian ini bertujuan untuk mengetahui respon eksplan vanili dengan stimulasi BAP atau NAA secara tunggal serta mengetahui interaksi stimulasi BAP dan NAA terhadap respon eksplan vanili melalui teknik mikropropagasi.

\section{METODOLOGI}

Penelitian

$$
\text { dilakukan }
$$

di Laboratorium Kultur Jaringan Politeknik Negeri Jember Jawa Timur Indonesia pada garis lintang $8^{\circ} 09^{\prime} 35.1$ "S $113^{\circ} 43 ' 27.2^{\prime \prime}$ E pada bulan Juni - Desember 2019. Penelitian didasarkan pada Rancangan Acak Lengkap (RAL) faktorial dengan 5 ulangan. Uji lanjutan menggunakan Beda Nyata Terkecil (BNT) pada taraf 5\%. Perlakuan berupa penambahan sitokinin dan auksin dalam medium dasar Murashige-Skoog (MS) dengan 100 mg.L1 inositol, 30 g.L-1 sukrosa, penentuan $\mathrm{pH}$ 5,7 - 5,8 dan 8 g.L-1 agar-agar. Faktor 1 adalah konsentrasi BAP 0.0 mg.L- $1 ; 1.0$ mg.L-1; 3.0 mg.L-1. Faktor 2 adalah konsentrasi NAA 0.0 mg.L-1; 0.5 mg.L-1

Bahan tanam yang akan digunakan sebagai eksplan adalah planlet vanili hasil aklimatisasi dan pemeliharaan di greenhouse Laboratorium Kultur Jaringan Politeknik Negeri Jember menggunakan paranet sebagai naungan $50 \%$ yang secara bertahap dibuka selama proses aklimatisasi. Tanaman aklimatisasi diperlakukan dengan penyiraman, pemupukan dan penyemprotan fungisida. Tanaman digunakan sebagai bahan tanam yang dipilih terlebih dahulu untuk mendapatkan bibit unggul. Tanaman yang diambil adalah tanaman yang segar, normal, sehat, dan bebas dari hama dan penyakit (Erawati et al. 2020). 
Persiapan eksplan dimulai dengan pemilihan sulur vanili yang sehat dan normal kemudian dicuci dengan air mengalir sampai bersih. Sterilisasi secara kimiawi dilakukan dalam Laminar Air Flow (LAF). Sulur vanili dicuci dengan larutan Tween $20 \%$ selama 5 menit dan kemudian dibilas dengan air suling steril. Eksplan disterilkan dengan merendam dalam larutan fungisida dan bakterisida $1,5 \%$ selama 60 menit dan kemudian direndam dalam alkohol $96 \%$ selama 5 detik. Eksplan direndam dalam larutan Bayclean 10\% (pemutih komersial dengan $5.25 \%$ natrium hipoklorit) selama 5 menit dan eksplan dibilas tiga kali dengan air suling steril (Ayele et al. 2017). Sulur vanili dipotong dan nodus vanili dengan panjang sekitar $1.5 \mathrm{~cm}$ sebagai eksplan (Tan et al. 2011).

Periode inkubasi dipertahankan pada suhu $26^{\circ} \mathrm{C} \pm 2^{0} \mathrm{C}$ dengan kelembaban relatif $60-70 \%$ di bawah siklus 16 jam cahaya dan 8 jam gelap dengan intensitas cahaya $40.5 \mu$ mol yang disediakan oleh lampu fluorescence.

\section{HASIL DAN PEMBAHASAN Kedinian Bertunas (hari)}

Pengamatan kedinian bertunas dilakukan setiap hari dan bertujuan untuk mengetahui kecepatan eksplan menghasilkan tunas. Berdasarkan Gambar 1 terlihat bahwa rerata kecepatan eksplan untuk membentuk tunas antara 7-17 hari setelah inokulasi. Penambahan Benzyl Amino Purine (BAP) dan Naphthalene Acetic Acid (NAA) tidak mempengaruhi kecepatan eksplan dalam membentuk tunas diduga karena eksplan yang digunakan berasal dari ruas batang dimana setiap eksplan telah memiliki calon mata tunas pada tiap ruas. Njoroge et al. (2015) juga melaporkan bahwa eksplan vanili yang berasal dari ruas batang mampu bertunas dalam kurun waktu 2 minggu dibandingkan dengan eksplan yang berasal dari daun muda vanili.

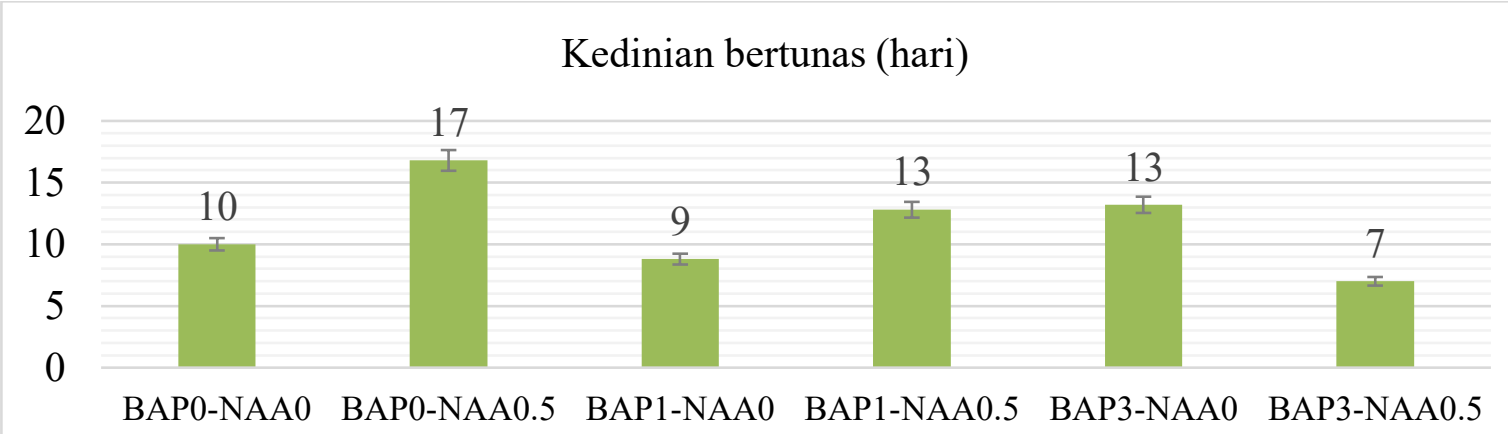

Gambar 1. Rerata kedinian bertunas eksplan vanili dengan stimulasi BAP dan NAA

Figure 1. The average sprouting rate of vanilla explants with BAP and NAA stimulation

Kecepatan eksplan vanili dalam membentuk tunas pada kurun waktu sekitar 2 minggu tanpa melalui fase pembentukan kalus akan memperkecil resiko variasi somaklonal. Hal ini sesuai dengan pendapat Lestari (2011) yang menyatakan bahwa kemampuan eksplan membentuk tunas secara langsung atau tanpa melalui fase kalus akan menjamin kestabilan secara genetik.

\section{Kemampuan Bertunas (\%)}

Kemampuan bertunas mengindikasikan kemampuan eksplan vanili dalam membentuk tunas sebagai tanda keberhasilan perbanyakan vegetatif melalui setek batang. Keberhasilan eksplan membentuk tunas sebesar $20-60 \%$ pada hari ke 7 dan $60-100 \%$ pada 14 hari setelah inokulasi (hsi). 
Tabel 1. Rerata Eksplan Vanili Bertunas dengan Stimulasi BAP dan NAA

Table 1. Average ability of vanilla explants to sprout with BAP and NAA stimulation

\begin{tabular}{llll}
\hline Stimulator (mg.L-1) & \multicolumn{2}{l}{ Rerata Kemampuan Bertunas $(\%)$} \\
\hline BAP & NAA & 7 hari setelah inokulasi & 14 hari setelah inokulasi \\
\hline 0.0 & 0.0 & 40 & 100 \\
\hline 0.0 & 0.5 & 0 & 60 \\
\hline 1.0 & 0.0 & 40 & 100 \\
\hline 1.0 & 0.5 & 20 & 80 \\
\hline 3.0 & 0.0 & 20 & 100 \\
\hline 3.0 & 0.5 & 60 & 100 \\
\hline & & $\mathrm{ns}$ & $\mathrm{ns}$ \\
\hline
\end{tabular}

Tabel 1 menunjukkan bahwa kemampuan eksplan untuk bertunas tidak tergantung pada penambahan stimulator eksogen. Cadangan makanan pada eksplan dan nutrisi media diduga mampu mencukupi kebutuhan eksplan untuk membentuk tunas. Restiani et al. (2016) mengemukakan bahwa berbagai jenis garam anorganik yang meliputi unsur makro, mikro, besi, vitamin, senyawa organik, dan senyawa organik kompleks merupakan komponen dasar penyusun medium yang berperan dalam mengoptimalkan pertumbuhan eksplan. Erawati et al. (2020) mengemukakan hasil yang sama bahwa pembentukan tunas pada eksplan vanili tidak dipengaruhi oleh penambahan zat pengatur tumbuh eksogen. Hasil yang berbeda dilaporkan oleh Renuga dan Kumar (2014) bahwa kemampuan eksplan vanili membentuk $95 \%$ tunas dipengaruhi oleh rasio BAP dan Kinetin sebesar 2:1.

\section{Jumlah Tunas (tunas)}

Penambahan stimulator BAP dan NAA ditujukan agar eksplan vanili mampu menggandakan tunas dan menghasilkan akar yang proporsional dalam perbanyakan vanili melalui teknik mikropropagasi. Tabel 2 memperlihatkan rerata jumlah tunas yang dihasilkan eksplan vanili dipengaruhi oleh penambahan BAP.

Tabel 2. Rerata Jumlah Tunas pada Eksplan Vanili dengan Penambahan BAP

Table 2. Average number of shoots on vanilla explants with the addition of BAP

\begin{tabular}{llllllllll}
\hline \multirow{2}{*}{$\begin{array}{l}\text { BAP } \\
(\mathrm{mg} . \mathrm{L}-1)\end{array}$} & $\begin{array}{l}\text { NAA } \\
(\mathrm{mg} . \mathrm{L}-1)\end{array}$ & \multicolumn{9}{l}{ Rerata Jumlah Tunas (tunas) } & \multicolumn{2}{l}{ 35 hsi } & $42 \mathrm{hsi}$ & & $49 \mathrm{hsi}$ & & $56 \mathrm{hsi}$ & \\
\hline 0.0 & 0.0 & 1.0 & $\mathrm{a}$ & 1.0 & $\mathrm{a}$ & 1.0 & $\mathrm{a}$ & 1.0 & $\mathrm{a}$ \\
\hline 1.0 & 0.0 & 3.0 & $\mathrm{~b}$ & 3.8 & $\mathrm{~b}$ & 5.8 & $\mathrm{~b}$ & 6.8 & $\mathrm{c}$ \\
\hline 3.0 & 0.0 & 2.4 & $\mathrm{ab}$ & 3.0 & $\mathrm{~b}$ & 3.6 & $\mathrm{~b}$ & 3.8 & $\mathrm{~b}$ \\
\hline
\end{tabular}

Berdasarkan Tabel 2 dapat diketahui bahwa rerata jumlah tunas terbanyak pada penambahan $1 \mathrm{mg} . \mathrm{L}-1$ BAP pada 56 hari setelah inokulasi (hsi) dengan rerata 6.8 tunas/eksplan tetapi tidak berbeda dengan penambahan 3 mg.L-1 BAP pada 35, 42 dan 49 hari setelah inokulasi. BAP merupakan zat pengatur tumbuh dari golongan sitokinin yang memang diperlukan untuk merangsang pertumbuhan tunas. Sitokinin mampu memacu pembelahan sel tunas sehingga menyebabkan pertumbuhan sel-sel meristem yang akan membelah dan berkembang menjadi tunas. Pemberian BAP dapat memacu sintesis protein sehingga mendorong terjadinya pembelahan sel yang menginduksi 
terbentuknya tunas. Lestari (2011) menyatakan bahwa untuk multiplikasi tunas memerlukan penambahan sitokinin. Lee-Espinosa et al. (2008) juga menyatakan bahwa penggandaan tunas vanili hanya dipengaruhi oleh penambahan BA $9.55 \mu \mathrm{M}$. Hal yang sama juga disampaikan oleh Abebe et al. (2009) bahwa multiplikasi tunas vanili yang terbaik pada penanaman di media MS yang diperkaya dengan BAP 1 mg.L-1.

\section{Tinggi Tunas (cm)}

Tinggi tunas merupakan reaksi pertumbuhan eksplan vanili dalam merespon penambahan BAP dan NAA kedalam media MS. Tinggi tunas diamati pada 56 hari setelah inokulasi dan dapat dilihat pada Tabel 3 .

Tabel 3. Rerata Tinggi Tunas pada Eksplan Vanili dengan Penambahan BAP dan NAA

Table 3. Average shoot height on vanilla explant with addition of BAP and NAA

\begin{tabular}{llll}
\hline \multicolumn{2}{l}{ Stimulator $(\mathrm{mg} . \mathrm{L}-1)$} & Rerata Tinggi Tunas $(\mathrm{cm})$ & \\
\hline BAP & NAA & 56 hari setelah inokulasi & \\
\hline 0.0 & 0.0 & 7.97 & $\mathrm{~b}$ \\
\hline 0.0 & 0.5 & 3.16 & $\mathrm{a}$ \\
\hline 1.0 & 0.0 & 1.75 & $\mathrm{a}$ \\
\hline 1.0 & 0.5 & 2.62 & $\mathrm{a}$ \\
\hline 3.0 & 0.0 & 1.84 & $\mathrm{a}$ \\
\hline 3.0 & 0.5 & 1.85 & $\mathrm{a}$ \\
\hline
\end{tabular}

Penambahan BAP dan NAA mempengaruhi tinggi tunas dengan tinggi tunas terpanjang terdapat pada perlakuan media dasar MS tanpa penambahan stimulator pertumbuhan eksplan denan rerata $7.97 \mathrm{~cm}$. Tunas pada eksplan tumbuh lebih tinggi karena tidak terjadi penggandaan tunas sehingga energi yang dimiliki sepenuhnya digunakan untuk pemanjangan tunas. Auksin merupakan hormon yang terdapat di meristem apikal dan berfungsi untuk merangsang tunas agar terus tumbuh ke atas, sedangkan sitokinin juga berperan dalam pemanjangan sel pada tanaman. Lingkungan eksternal dan internal juga mendukung pertumbuhan tinggi tunas. Kebutuhan lingkungan eksternal selama periode inkubasi sesuai dan hara makro, hara mikro, vitamin serta sukrosa yang ada didalam media tersedia. Jadid et al. (2015) menyatakan bahwa ekplan dari ruas vanili yang diinokulasi pada media dasar MS tanpa penambahan zat pengatur tumbuh akan menghasilkan tunas yang tumbuh memanjang. Erawati et al., (2020) mengemukakan lebih lanjut bahwa jumlah tunas berkorelasi negatif dengan panjang tunas, dimana semakin banyak tunas yang terbentuk akan mempengaruhi panjang tunas yang lebih pendek, sehingga energi yang dibutuhkan untuk tinggi pucuk lebih banyak digunakan untuk multiplikasi tunas.

\section{Berat Basah (gram)}

Respon eksplan vanili terhadap stimulator BAP dan NAA dapat diukur dari berat basah eskplan. Berat basah eksplan dihitung pada 56 hari setelah inokulasi dan rerata berat basah tersaji pada gambar 2 . Berdasarkan hasil analisis sidik ragam dapat diketahui bahwa berat basah tidak dipengaruhi oleh penambahan zat pengatur tumbuh kedalam media dasar meskipun jumlah tunas memiliki reaksi yang berbeda terhadap penambahan zat pengatur tumbuh eksogen. 


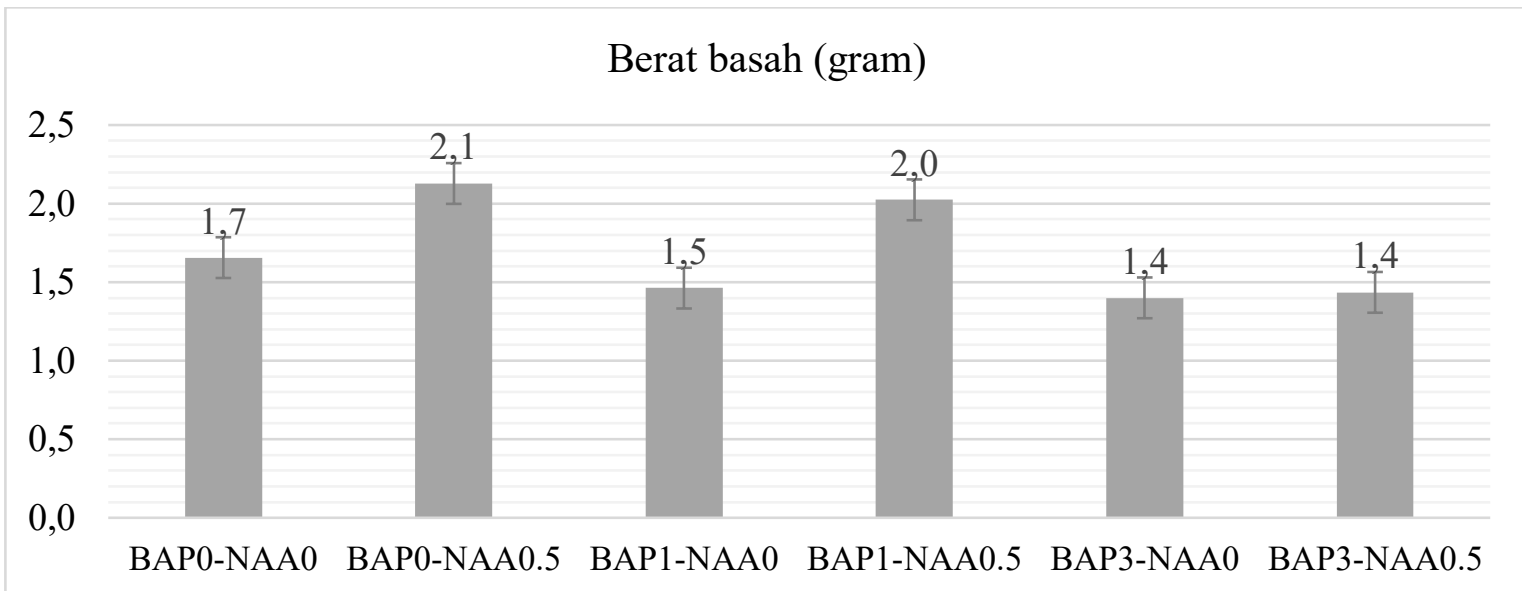

Gambar 2. Rerata Berat Basah Eksplan Vanili pada Penambahan BAP dan NAA

Figure 2. Average wet weight of vanilla explants on the addition of BAP and NAA

Berdasar Gambar 2 diketahui bahwa rerata berat basah eksplan berkisar antara 1.4-2.1 gram. Berat basah yang tidak berbeda antar perlakuan ini karena eksplan yang berhasil menggandakan tunas tidak memiliki jumlah akar yang cukup,

sedangkan eksplan yang jumlah penggandaan tunas lebih sedikit mempunyai berat akar yang lebih berat. Perkembangan dan pertumbuhan eksplan pada masing-masing perlakuan dapat dilihat pada gambar 3 .
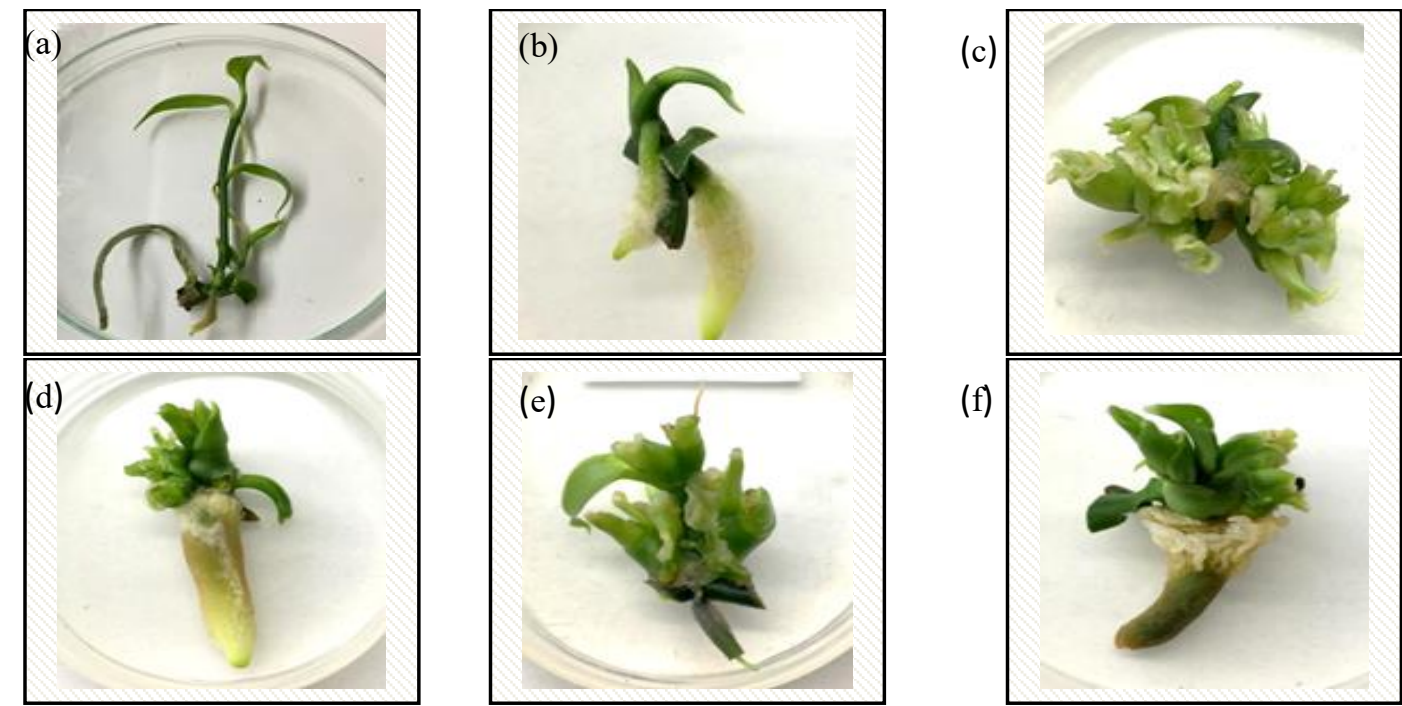

Gambar 3. Pertumbuhan eksplan vanili pada penambahan stimulator BAP dan NAA Figure 3. Growth of vanilla explants on addition of BAP and NAA stimulators

Keterangan:

(a) Eksplan pada perlakuan BAP 0.0 ; NAA $0.0 \mathrm{mg} /$ liter

(b) Eksplan pada perlakuan BAP 0.0 ; NAA $0.5 \mathrm{mg} /$ liter

(c) Eksplan pada perlakuan BAP 1.0 ; NAA $0.0 \mathrm{mg} /$ liter

(d) Eksplan pada perlakuan BAP 1.0 ; NAA $0.5 \mathrm{mg} /$ liter

(e) Eksplan pada perlakuan BAP 3.0 ; NAA $0.0 \mathrm{mg} /$ liter

(f) Eksplan pada perlakuan BAP 3.0 ; NAA $0.5 \mathrm{mg} /$ liter 
Pemberian auksin dalam jumlah konsentrasi lebih tinggi dibandingkan sitokinin cenderung mengarah terhadap pertumbuhan akar sedangkan pemberian konsentrasi auksin yang lebih rendah dibandingkan sitokinin akan menumbuhkan pembentukan tunas pada eksplan.

\section{Jumlah Akar (akar)}

Upaya perbanyakan vegetatif vanili melalui teknik mikropropagasi memiliki keuntungan karena lebih cepat, lebih hemat bahan tanam, tidak merusak pohon induk dan sifat keturunan yang sama dengan induk. Tetapi penggunaan eksplan 1 ruas batang vanili memerlukan tambahan zat pengatur tumbuh sintetik dari golongan sitokinin dan auksin agar eksplan mampu membentuk tunas dan akar lebih banyak. Respon eksplan vanili terhadap jumlah akar akibat penambahan BAP dan NAA tertera pada Tabel 4.

Tabel 4. Rerata Jumlah Akar pada Eksplan Vanili pada Penambahan BAP dan NAA

Table 4. Average Number of Roots in Vanilla Explants on Addition of BAP and NAA

\begin{tabular}{llll}
\hline \multicolumn{2}{l}{ Stimulator (mg.L-1) } & \multicolumn{2}{c}{ Rerata Jumlah Akar (buah) } \\
\hline BAP & NAA & 56 hari setelah inokulasi \\
\hline 0.0 & 0.0 & 2.6 & $\mathrm{c}$ \\
\hline 0.0 & 0.5 & 3.0 & $\mathrm{c}$ \\
\hline 1.0 & 0.0 & 0.4 & $\mathrm{a}$ \\
\hline 1.0 & 0.5 & 1.2 & $\mathrm{~b}$ \\
\hline 3.0 & 0.0 & 0.4 & $\mathrm{a}$ \\
\hline 3.0 & 0.5 & 1.0 & $\mathrm{ab}$
\end{tabular}

Penambahan NAA secara tunggal menghasilkan jumlah akar yang lebih banyak. NAA termasuk dalam golongan auksin yang berperan sebagai stimulator pembentuk akar pada eksplan. Hasil penelitian Tan et al. (2011) memperlihatkan bahwa $88.33 \%$ eksplan vanili membentuk akar dengan penambahan NAA sebanyak $1 \mathrm{mg} /$ liter dengan rata-rata panjang akar $4.4 \mathrm{~cm}$ setelah 4 minggu. Lebih lanjut LeeEspinosa et al. (2008) menyampaikan hasil penelitian bahwa akar pada eksplan vanili terbentuk hanya dipengaruhi oleh NAA pada konsentrasi $0.44 \mu \mathrm{M}$.

\section{KESIMPULAN}

Stimulasi BAP secara tunggal mempengaruhi multiplikasi tunas vanili dengan rerata jumlah tunas terbanyak 6.8 tunas/eskplan pada stimulasi BAP $1 \mathrm{mg}$.L1 dan stimulasi NAA secara tunggal menginduksi pembentukan akar dengan rerata jumlah akar terbanyak 3.0 akar/eksplan pada stimulasi NAA 0.5 mg.L-1.

\section{DAFTAR PUSTAKA}

Abebe, Z., Mengesha, A., Teressa, A., \& E Tefera, W. (2009). Efficient in vitro multiplication protocol for Vanilla planifolia using nodal explants in Ethiopia. African Journal of Biotechnology, 8(24).

Ayele, Y. B., Tefera, W., \& Bantte, K. EQ (2017). Enhanced Protocol Development for in vitro Multiplication and Rooting of Vanilla (Vanilla planifolia Andr.) Clone (Van. 2/05). Biotechnology Journal International, 1-11.

Erawati, D. N., Wardati, I., Humaida, S., \& EQ Fisdiana, U. (2020). Micropropagation of Vanilla (Vanilla planifolia Andrews) with Modification of Cytokinins. IOP 
Conference Series: Earth and Environmental Science, 411(1), 12009.

Jadid, N., Nurhidayati, T., \& Priyono, P. 的 (2015). In Vitro Clonal Propagation of Vanilla planifolia Andrews Using Microshoot-derived Node Explants. $J$. Appl. Environ. Biol. Sci., 5(6), 105110.

Lee-Espinosa, H. E., Murgu \’ia-González, EQ J., Garcl'lia-Rosas, B., CórdovaContreras, A. L., Laguna-Cerda, A., Mijangos-Cortés, J. O., ... SantanaBuzzy, N. (2008). In vitro clonal propagation of vanilla (Vanilla planifolia 'Andrews'). HortScience, 43(2), 454-458.

Lestari, E. G. (2011). Peranan zat pengatur tumbuh dalam perbanyakan tanaman melalui kultur jaringan. Jurnal AgroBiogen, 7(1), 63-68.

Loedji, H. (2019). 8 Besar Produk 住 Pertanian Indonesia. PortoNews.

Njoroge, A. M., Gitonga, L., Mutuma, E., EQ Mimano, L., Macharia, C., Wasilwa, L., ... Mungai, A. (2005). Propagation of high quality planting materials of Vanilla (Vanilla planifolia) through tissue culture. Kenya Agricultural Research Institute (KARI), Thika National Agricultural Research Laboratories NairobiKenya, 1-4.

Palama, T. L., Menard, P., Fock, I., Choi, EQ Y. H., Bourdon, E., GovindenSoulange, J., ... Kodja, H. (2010). Shoot differentiation from protocorm callus cultures of Vanilla planifolia (Orchidaceae): proteomic and metabolic responses at early stage. BMC Plant Biology, 10(1), 82.
Pinaria, A. G., Liew, E. C. Y., \& Burgess, Q L. W. (2010). Fusarium species associated with vanilla stem rot in Indonesia. Australasian Plant Pathology, 39(2), 176-183.

Renuga, G., \& Saravana-Kumar, S. N. EQ (2014). Induction of vanillin related compounds from nodal explants of Vanilla planifolia using BAP and Kinetin. Asian J. Plant Sci. Res, 4(1), 53-61.

Restiani, R., Semiarti, E., \& Indrianto, A. EQ (2016). Konservasi anggrek hitam (Coelogyne pandurata Lindl.) melalui mikropropagasi pada berbagai medium kultur. Prosiding Simposium Nasional Pendidikan Biologi (Symbion 2016), 27, 393-404.

Tan, B. C., Chin, C. F., \& Alderson, P. (2011). Optimisation of plantlet regeneration from leaf and nodal derived callus of Vanilla planifolia Andrews. Plant Cell, Tissue and Organ Culture (PCTOC), 105(3), 457-463. 